\title{
25. BERRIASIAN TO APTIAN DINOFLAGELLATE CYSTS FROM THE GALICIA MARGIN, OFFSHORE SPAIN, SITES 638 AND 639, ODP LEG 103'
}

\author{
Edwige Masure, Laboratoire de Micropaléontologie, C.N.R.S.-U.A. 319, Université Pierre et Marie Curie, Paris, \\ France
}

\begin{abstract}
The dinoflagellate cyst assemblages in 42 samples collected from Sites 638 and 639 were analyzed. All samples from Site 639 are barren; relatively poor assemblages occur in samples from Site 638 . The distribution of 61 dinoflagellate cyst taxa identified in samples from Holes $638 \mathrm{~B}$ and $638 \mathrm{C}$ are tabulated.

The assemblages from Site 638 are comparable to those of Tethyian stratotypes and from neighboring areas, which permits age determinations and correlations between Holes 638B and 638C. The interval from Cores 103-638C-14R to $103-638 \mathrm{C}-1 \mathrm{R}$ is late Berriasian through Valanginian in age. In Hole 638B, the interval from Core 103-638B-43R to Section 103-638B-23R-2 is dated as early Valanginian through middle Barremian. Sections 103-638B-21R-2 and 103-638B21R-1 are late Aptian in age.

Taxonomic remarks are made about some species; a new dinoflagellate cyst Heterosphaeridium? galiciae is described.
\end{abstract}

\section{INTRODUCTION}

Sites 638 and 639, drilled during Leg 103 of the Ocean Drilling Program (ODP), are at the southwestern edge of the Galicia margin on a tilted fault block (Fig. 1) (see "Site 638" and "Site 639" chapters; Boillot, Winterer, et al., 1987). Three holes were drilled at Site 638 . Hole $638 \mathrm{~A}$ was drilled as a test hole and no cores were collected; samples from the other two holes drilled (Holes 638B and 638C) were studied. At Site 639, a total of six holes were drilled (Holes 639A through 639F). Samples from three holes were analyzed (Holes 639A, 639C, and 639D), and all are barren.

The main objectives of this study are to investigate dinoflagellate cyst assemblages and to assign ages to the recovered core material. A list of the samples examined from Holes 638B, $638 \mathrm{C}, 639 \mathrm{~A}, 639 \mathrm{C}$, and $639 \mathrm{D}$ is provided in Table 1. A total of 42 samples were prepared using common palynological techniques. All residues were filtered through sieves of $10-\mu \mathrm{m}$ mesh. Residues were spread in glycerine jelly.

Samples from Site 638 yielded dinoflagellate cyst assemblages with few individuals that were usually poorly preserved, particularly those from Hole $638 \mathrm{C}$. Nevertheless, analysis of these dinoflagellate cyst assemblages made age determination of the sediment possible. The first part of the paper presents the biostratigraphic data from the bottom to the top of the section in Holes $638 \mathrm{~B}$ and $638 \mathrm{C}$. The second part details dinoflagellate cyst taxonomy.

\section{BIOSTRATIGRAPHY OF SITE 638}

The dinoflagellate cyst assemblages of Early Cretaceous age that were recovered at Site 638 show close affinities with those known from the western North Atlantic and from the Tethyian provinces of Mediterranean Europe and Africa. The Tethyian dinoflagellate cyst assemblages of Berriasian to Aptian age were first described by Millioud $(1967,1969)$ in southeast France. Habib (1977) defined five dinoflagellate cyst zones ranging in age from late Berriasian to early Albian from Deep Sea Drilling Project (DSDP) drill sites. This zonation was applied to the west-

${ }^{1}$ Boillot, G., Winterer, E. L., et al., 1988. Proc. ODP, Sci. Results, 103: College Station, TX (Ocean Drilling Program). ern North Atlantic and was later compared with Early Cretaceous stratotypes and parastratotypes (Habib and Drugg, 1983). Jardiné et al. (1984) proposed nine palynologic-planktonic zones correlated with ammonite zonations from the Berriasian to late Aptian stratotypes and parastratotypes of southeast France.

Many age-diagnostic species from these two zonations were observed in this study, but the basal range of some of these species did not occur in the expected succession. Therefore, age determinations of the Leg 103 samples are based on comparison to these dinoflagellate cyst zonations, as well as to cyst assemblages known from the south of France (Srivastava, 1984; Monteil, 1985), DSDP Holes 370 (Williams, 1978), 400 and 402 (Davey, 1979b), and 398D (Masure, 1984), and well-dated Moroccan sections (Below, 1981a, 1982a, 1982b).

\section{Hole $638 \mathrm{C}\left(42^{\circ} 09.2^{\prime} \mathrm{N}, 12^{\circ} 11.8^{\prime} \mathrm{W}\right.$; water depth $4661 \mathrm{~m})$}

A total of $135 \mathrm{~m}$ of Lower Cretaceous sediments was cored in Hole 638C (Cores 103-638C-1R through 103-638C-14R; 411.9$547.2 \mathrm{~m}$ below seafloor [mbsf]). The recovered sediments consist of numerous thick sandstone layers interbedded with minor siltstone, claystone, and marlstone layers (Subunit IIIB, as described by the Shipboard Scientific Party, 1987a). Nannofossil analysis suggests that the sediments recovered from Hole $638 \mathrm{C}$ are of late Valanginian to Hauterivian age (as assigned in the "Biostratigraphy" section of the "Site 638" chapter; Shipboard Scientific Party, 1987a). Thirteen samples were analyzed from this interval. The dinoflagellate cyst assemblages are poorly diversified with few individuals.

Marine palynomorphs recovered from these 13 samples are tabulated in Figure 2. Samples 103-638C-9R-2, 54-56 cm, 103$638 \mathrm{C}-4 \mathrm{R}-4,45-47 \mathrm{~cm}$, and 103-638C-1R-2, 49-51 cm, are barren of dinoflagellate cysts.

\section{Late Berriasian-Early Valanginian?}

From the recovered dinocyst species, a late Berriasian or probable Valanginian age is proposed for the interval from Samples $103-638 \mathrm{C}-14 \mathrm{R}-1,128-130 \mathrm{~cm}$, to $103-638 \mathrm{C}-8 \mathrm{R}-1,78-80 \mathrm{~cm}$.

Sample 103-638C-14R-1, 128-130 cm, yielded few morphotypes. Achomosphaera? neptunii, Phoberocysta neocomica, and Pseudoceratium pelliferum have first stratigraphic occurrences at the top of the upper Ryazanian in the North realm (Davey, $1979 \mathrm{c})$. In the Tethyian realm, $A$.? neptunii and $P$. neocomica 
A

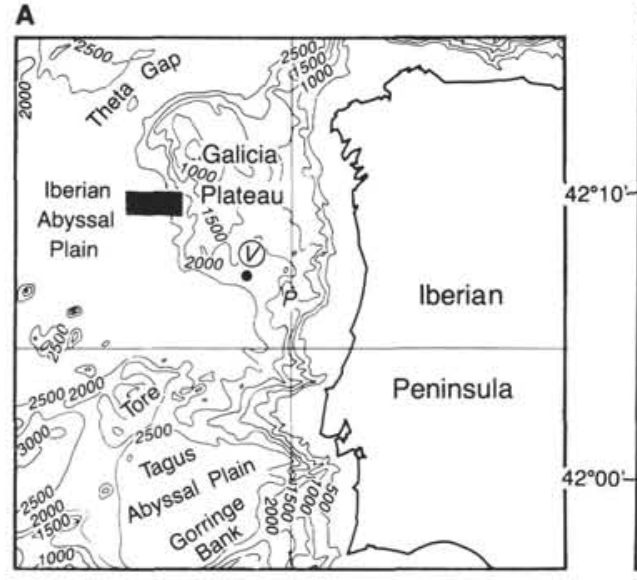

B

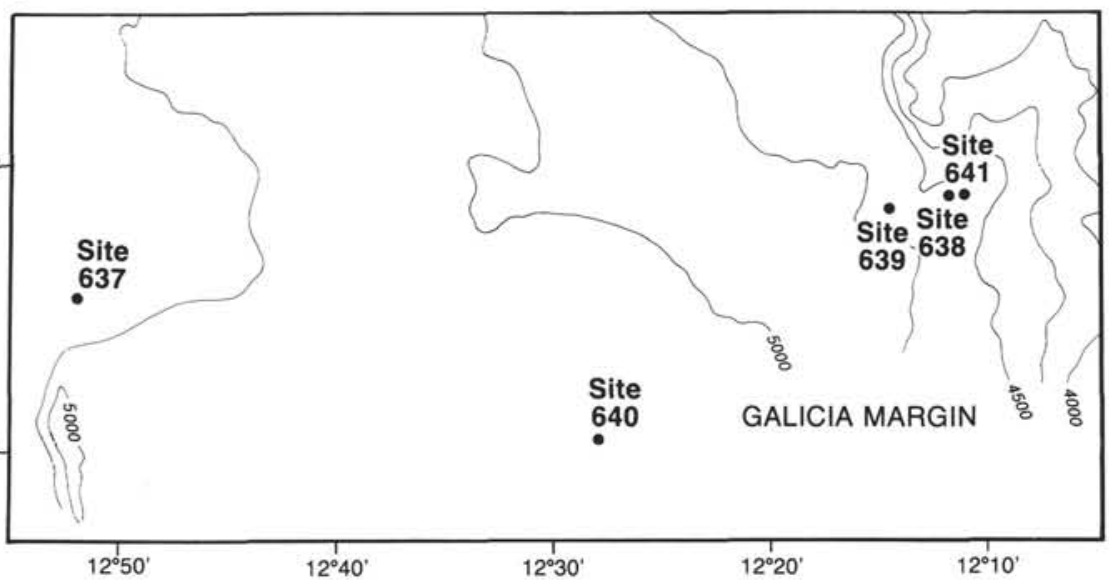

Figure 1. A. General location map of Galicia margin. Boxed area shown in Figure 1B. V = Vigo Seamount. Dot is location of Site 398. B. Location of sites drilled on ODP Leg 103. Bathymetry in meters.

Table 1. List of samples studied. All samples from Site 639 are barren of dinoflagellate cysts.

\begin{tabular}{lc}
\hline \multicolumn{1}{c}{ Site 638} & Site 639 \\
\hline Hole $638 \mathrm{C}$ & Hole $639 \mathrm{~A}$ \\
$1 \mathrm{R}-2,49-51 \mathrm{~cm}$ & $4 \mathrm{R}, \mathrm{CC}(7-8 \mathrm{~cm})$ \\
$3 \mathrm{R}-1,59-61 \mathrm{~cm}$ & $5 \mathrm{R}-2,38-40 \mathrm{~cm}$ \\
$3 \mathrm{R}-3,41-43 \mathrm{~cm}$ & $6 \mathrm{R}-2,30-32 \mathrm{~cm}$ \\
$4 \mathrm{R}-2,8-10 \mathrm{~cm}$ & $7 \mathrm{R}-1,129-131 \mathrm{~cm}$ \\
$4 \mathrm{R}-4,45-47 \mathrm{~cm}$ & $7 \mathrm{R}-3,54-56 \mathrm{~cm}$ \\
$5 \mathrm{R}-1,140-142 \mathrm{~cm}$ & $8 \mathrm{R}-1,84-86 \mathrm{~cm}$ \\
$6 \mathrm{R}-2,69-71 \mathrm{~cm}$ & \\
$7 \mathrm{R}-2,39-41 \mathrm{~cm}$ & Hole $639 \mathrm{C}$ \\
$8 \mathrm{R}-1,78-80 \mathrm{~cm}$ & \\
$9 \mathrm{R}-2,54-56 \mathrm{~cm}$ & $2 \mathrm{R}-1,89-91 \mathrm{~cm}$ \\
$10 \mathrm{R}-2,87-91 \mathrm{~cm}$ & \\
$13 \mathrm{R}-1,18-20 \mathrm{~cm}$ & Hole $639 \mathrm{D}$ \\
$14 \mathrm{R}-1,128-130 \mathrm{~cm}$ & \\
& $5 \mathrm{R}-1,53-54 \mathrm{~cm}$ \\
Hole $638 \mathrm{~B}$ & $7 \mathrm{R}-3,67-68 \mathrm{~cm}$ \\
& $8 \mathrm{R}-2,18-20 \mathrm{~cm}$ \\
$21 \mathrm{R}-1,121-123 \mathrm{~cm}$ & $10 \mathrm{R}-2,13-14 \mathrm{~cm}$ \\
$21 \mathrm{R}-2,121-123 \mathrm{~cm}$ & \\
$23 \mathrm{R}-2,34-36 \mathrm{~cm}$ & \\
$23 \mathrm{R}-4,40-42 \mathrm{~cm}$ & \\
$24 \mathrm{R}-5,69-71 \mathrm{~cm}$ & \\
$26 \mathrm{R}-5,91-93 \mathrm{~cm}$ & \\
$27 \mathrm{R}-3,126-128 \mathrm{~cm}$ & \\
$28 \mathrm{R}-6,89-91 \mathrm{~cm}$ & \\
$29 \mathrm{R}-1,92-94 \mathrm{~cm}$ & \\
$29 \mathrm{R}-3,35-37 \mathrm{~cm}$ & \\
$30 \mathrm{R}-1,144-146 \mathrm{~cm}$ & \\
$33 \mathrm{R}-2,64-66 \mathrm{~cm}$ & \\
$34 \mathrm{R}-2,95-97 \mathrm{~cm}$ & \\
$34 \mathrm{R}, \mathrm{CC}(18-20 \mathrm{~cm})$ & \\
$35 \mathrm{R}-1,84-86 \mathrm{~cm}$ & \\
$36 \mathrm{R}-2,21-23 \mathrm{~cm}$ & \\
$37 \mathrm{R}-1,46-48 \mathrm{~cm}$ & \\
$43 \mathrm{R}-1,29-30 \mathrm{~cm}$ & \\
\hline
\end{tabular}

have been reported from the lower Berriasian (Habib and Drugg, 1983 ) and from the middle Berriasian (P. neocomica) (Jardiné et al., 1984). P. pelliferum appears in the late Berriasian (Habib and Drugg, 1983; Jardiné et al., 1984). Therefore, a late Berriasian age can be assigned to Sample 103-638C-14R-1, 128-130 $\mathrm{cm}$, but an early Valanginian age cannot be completely dismissed.

The few individuals in the poorly diversified dinoflagellate cyst assemblages in Samples 103-638C-13R-1, 18-20 cm, to 103-
$638 \mathrm{C}-8 \mathrm{R}-1,78-80 \mathrm{~cm}$, provide little information for age determination. Dapsilidinium warrenii, which occurs in Sample 103$638 \mathrm{C}-13 \mathrm{R}-1,18-20 \mathrm{~cm}$, is known to appear early in the middle Berriasian (Occitanica ammonite zone; Jardiné et al. 1984). In Sample 103-638C-8R-1, 78-80 cm, Tanyosphaeridium magneticum occurs, and it has been described from the Valanginian of arctic Canada (Davies, 1983) and recorded from the upper Valanginian in southwest France (Monteil, 1985).

\section{Valanginian}

The interval from Samples 103-638C-7R-2, 39-41 cm, to $103-638 \mathrm{C}-1 \mathrm{R}-2,49-51 \mathrm{~cm}$, is of early Valanginian-Valanginian age.

The presence of Druggidium apicopaucicum and Dingodinium cerviculum in Sample 103-638C-7R-2, 39-41 cm, is significant. D. apicopaucicum is a selected species of the dinoflagellate cyst zonations of Habib (1977); the D. apicopaucicum Zone characterizes the lower Valanginian through the upper Valanginian. In Lower Cretaceous stratotypes, the first occurrence of $D$. apicopaucicum is in the lower Valanginian, in the Pertransiens ammonite zone, which is Drugg and Habib's (1983) first ammonite zone of the lower Valanginian. Jardiné et al. (1984) also recorded the first occurrence of D. apicopaucicum in the Pertransiens ammonite zone, which is the second ammonite zone of the lower Valanginian for these authors (the first ammonite zone is the Otopeta Zone). D. cerviculum has a sporadic first stratigraphic occurrence in the lower Valanginian (Jardiné et al., 1984; Monteil, 1985) and a persistent occurrence in the upper Valanginian (Jardiné et al., 1984). D. cerviculum has been observed within the lowermost Valanginian in well-dated sections of Morocco (Below, 1982a). For the Tethyian realm, Williams and Bujak (1985) considered the first occurrence of D. cerviculum as late early Valanginian. But D. cerviculum is known also to appear earlier, in the Berriasian (Duxbury, 1977; Habib, 1978; Williams and Bujak, 1980; Habib and Drugg, 1987).

Biorbifera johnewingii occurs in Sample 103-638B-7R-2, 39$41 \mathrm{~cm}$. Jardiné et al. (1984) found the first occurrence of $B$. johnewingii at the base of the Occitanica ammonite zone of the middle Berriasian. Habib and Drugg (1983) considered the first occurrence of B. johnewingii in the Berriasella privasensis ammonite subzone of the Bossieri Zone. Sample 103-638C-6R-2, $69-71 \mathrm{~cm}$, contains Spiniferites multibrevis (= Spiniferites ramosus subsp. multibrevis). In the Lower Cretaceous stratotypes and parastratotypes of southeast France, the $S$. ramosus group has a basal stratigraphic occurrence within the lower Valanginian (J. 


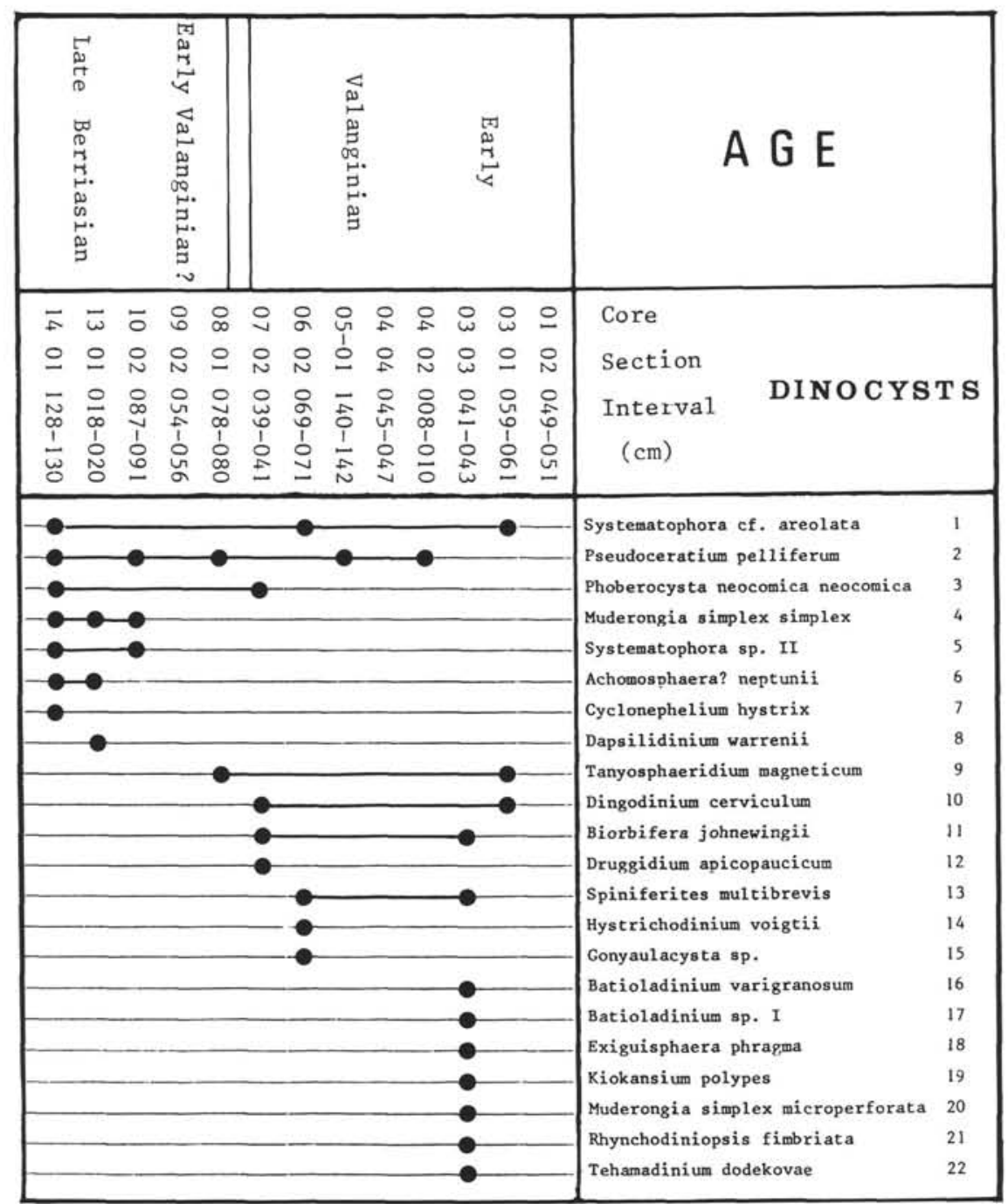

Figure 2. Distribution chart of dinoflagellate cysts of Cretaceous age from Hole $638 \mathrm{C}$.

F. Raynaud, pers. comm., 1987). In DSDP Hole 370 (Williams, 1978 ) and in Moroccan sections (Below, 1982b), S. ramosus has a basal occurrence at the base of the Valanginian. In northwest Europe, $S$. ramosus is a selected species that characterizes the lower Valanginian (Davey, 1979c). No additional species are introduced as components in the dinoflagellate cyst assemblages in the interval between Samples 103-638C-5R-1, 140-142 cm, and $103-638 \mathrm{C}-4 \mathrm{R}-2,8-10 \mathrm{~cm}$.

The presence of B. johnewingii in Sample 103-638C-3R-3, $41-43 \mathrm{~cm}$, is significant. The last occurrence of this form is found in the upper Valanginian. Therefore, a Valanginian age is expected for Sample 103-638C-4R-2, 8-10 cm. The dinoflagellate cyst assemblages in Sample 103-638C-3R-3, 41-43 cm, consist of species that have ranges mainly in the Valanginian. Exiguisphaera phragma has been reported from the lower Valanginian of northwest Germany (Below, 1981b), offshore Denmark (Davey, 1982), and southeast France (Monteil, 1985). Tehamadinium dodekovae was described from the lower Valanginian of the Speeton Clay (Jan du Chêne et al., 1986a). Batioladinium varigranosum ( = Aprobolocysta varigranosa) has been reported from the uppermost Berriasian through the Valanginian of the Neocomian stratotype (Habib and Drugg, 1983).

\section{Hole 638B $\left(42^{\circ} 09.2^{\prime} \mathrm{N}, 1^{\circ}{ }^{\circ} 11.8^{\prime} \mathrm{W}\right.$; water depth $4661 \mathrm{~m})$}

A total of $364 \mathrm{~m}$ of Lower Cretaceous sediments was cored in Hole 638B between Cores 103-638B-20R and 103-638B-45R (Shipboard Scientific Party, 1987a). The sequence defined by the shipboard scientific party as lithologic Unit III, between Samples 103-638B-45R, CC (25 cm), and 103-638B-32R-2, 95 $\mathrm{cm},(431.1-298.4 \mathrm{mbsf})$ is divided into two subunits. The lower subunit (Subunit IIIB), from Samples 103-638B-45R, CC (25 $\mathrm{cm}$ ), to $103-638 \mathrm{~B}-35 \mathrm{R}-4,55 \mathrm{~cm}$, consists of thick beds of terrigenous sandstone. This subunit is equivalent to sediments of Hole 638C (see "Site 638" and "Site 639" chapters; Shipboard Scientific Party, 1987a, 1987b). The upper subunit (Subunit IIIA), from Samples 103-638B-35R-4, $55 \mathrm{~cm}$, to 103-638B-32R-2, 95 $\mathrm{cm}$, consists of thin-bedded claystone and marlstone. The age assigned by the shipboard scientific party based on the nannofossil assemblages in Cores 103-638B-30R through 103-638B-45R is late Valanginian to early Hauterivian.

Lithologic Unit II, between Samples 103-638B-32R-2, $95 \mathrm{~cm}$, and 103-638B-20R-3, $3 \mathrm{~cm},(298.4-183.6 \mathrm{mbsf})$ is divided into two subunits. An unconformity is recognized between these two 
subunits at Sample 103-638B-23R-3, $27 \mathrm{~cm}$. The lower subunit (Subunit IIB), from Samples 103-638B-32R-2, $95 \mathrm{~cm}$, to $103-$ 638B-23R-3, $27 \mathrm{~cm}$, consists of white laminated nannofossil limestone. A Hauterivian age is assigned by the shipboard scientific party to nannofossils to the interval from Sample 103-638B$23 \mathrm{R}-4,55-56 \mathrm{~cm}$, through Section 103-638B-29R, CC. The upper subunit (Subunit IIA), from Samples 103-638B-23R-3, 27 $\mathrm{cm}$, to $103-638 \mathrm{~B}-20 \mathrm{R}-3,3 \mathrm{~cm}$, contains rich terrigenous material. This upper subunit is dated as late Barremian by the shipboard scientific party.

Eighteen samples were analyzed from Cores 103-638B-43R to $103-638 \mathrm{~B}-21 \mathrm{R}$ (Table 1). The distribution of the 52 taxa identified in these samples is given in Figure 3.

\section{Valanginian}

The interval from Samples 103-638B-43R-1, 29-30 cm, to 103-638B-34R, CC (18-20 cm), is of early Valanginian-Valanginian age. Only seven species were observed in Sample 103638B-43R-1, 29-30 cm, two of which have stratigraphic meaning: D. apicopaucicum and $S$. ramosus. D. apicopaucicum characterizes the Valanginian (Habib, 1977). In Lower Cretaceous stratotypes, the first occurrence of $D$. apicopaucicum is in the Valanginian in the Pertransiens ammonite zone (Habib and Drugg, 1983) (Jardiné et al., 1984). The appearance of S. ramosus in the early Valanginian is well known (J. F. Raynaud, pers. comm., 1987; Davey, 1979c). Only few forms are present as additional index species in the dinoflagellate cyst assemblages from Samples 103-638B-36R-2, 21-23 cm, to 103-638B-34R, CC $(18-20 \mathrm{~cm})$, and these confirm the last assignment.

Samples 103-638B-34R-2, 95-97 cm, to 103-638B-30R-1, 144$146 \mathrm{~cm}$, are of late Valanginian age. Sample 103-638B-34R-2, 95-97 cm, contains B. johnewingii and Ctenidodinium elegantulum. The last occurrence of $B$. johnewingii is well known in the upper Valanginian of southern France (Angles sections) at the top of Verrucosum ammonite zone, the first ammonite zone of the upper Valanginian (Jardiné et al., 1984). Habib and Drugg (1983) considered the last occurrence of B. johnewingii in the Himantoceras trinodosum ammonite subzone. In Moroccan sections, the first occurrence of $C$. elegantulum is within the uppermost Valanginian (Below, 1982a). Therefore, the basal range of this species is known from the Berriasian (Habib and Drugg, 1983; Williams and Bujak, 1985). Oligosphaeridium dividuum occurs in Sample 103-638B-30R-1, 144-145 cm. This form has been described from the Valanginian samples of DSDP Hole 370 (Williams, 1978). In Moroccan onshore sections, O. dividuum first occurs in the upper Valanginian (Below, 1982a).

\section{Hauterivian}

The interval from Samples 103-638B-29R-3, 35-37 cm, to 103-638B-28R-6, $89-91 \mathrm{~cm}$, is of early Hauterivian age. Sample 103-638B-29R-3, 35-37 cm, contains Protoellipsodinium touile subsp. mugatae. This species has been reported from the lower Hauterivian of well-dated onshore sections of Morocco (Below, 1981, 1982a). Wallodinium krutzschii, which occurs in Sample 103-638B-28R-6, 89-91 cm, is found within the lower Hauterivian of the Moroccan sections (Below, 1981b, 1982a). This species is known to range from the Berriasian to the Barremian. As in Morocco, W. krutzschii in Hole 638B seems to have an early Hauterivian age; this basal range may be related to environmental features.

The interval from Samples 103-638B-27R-3, 126-128 cm, to 103-638B-24R-5, 69-71 cm, is of late Hauterivian age. D. rhabdoreticulatum occurs in Sample 103-638B-27R-3, 126-128 cm. D. rhabdoreticulatum is a selected species of the dinoflagellate cyst zonation of Habib (1977); the D. rhabdoreticulatum Zone characterizes the upper lower Hauterivian through the upper Hauterivian. In Lower Cretaceous stratotypes and parastratotypes, the first occurrence of $D$. rhabdoreticulatum has been reported from the upper Hauterivian (Jardiné et al., 1984); the same is found in DSDP Hole 534A (Habib and Drugg, 1983). Habib and Drugg (1983) considered the last occurrence of $D$. rhabdoreticulatum in the upper Aptian. The last occurrence of D. rhabdoreticulatum has been reported from the middle Albian (Williams and Bujak, 1985). No index species are introduced as additional components in the dinoflagellate cyst assemblages in Samples 103-638B-26R-5, 91-93 cm, and 103-638B24R-5, 69-71 cm.

Sample 103-638B-23R-4, 40-42 cm, is of late Hauterivian age. This sample contains six additional species, one of which has stratigraphic significance: Bourkidinium granulatum. This form, described from the Australian Albian section (Morgan, 1975), has been reported from the lower Barremian of southeast France (Srivastava, 1984). The morphotype has been also recorded in arctic Canada (age unknown; Davies, 1983) and in the lower Albian of the Speeton Clay (Duxbury, 1983). Bourkidinium (as Bourkidinium sp.) is present in the upper Hauterivian of Hole 603B (Habib and Drugg, 1987) and in the upper Hauterivian at Route d'Angles (W. S. Drugg, unpubl. data). The other associated species have large ranges or appear in Moroccan sections of Hauterivian age, as Florentinia radiculata (Below, 1982b).

\section{Middle Barremian}

Sample 103-638B-23R-2, 34-36 cm, is of middle Barremian age and contains Cerbia tabulata and Kleithriasphaeridium eionodes. In southwestern France, the first appearance of Cerbia tabulata is recorded in the upper Barremian (Jardiné et al., 1984). In Moroccan sections, C. tabulata has been reported in the middle Barremian (Below, 1982b), as it is in world range charts ( $=$ C. tabulata) (Williams and Bujak, 1985). C. tabulata has a range from the middle Barremian through Aptian (Williams and Bujak, 1985). Therefore, the oldest age suggested by the assemblage in Sample 103-638B-23R-2, 34-36 cm, is middle Barremian, but an Aptian age cannot be completely dismissed.

\section{Aptian}

Samples 103-638B-21R-2, 121-123 cm, and 103-638B-21R-1, 121-123 cm, are of late Aptian age. Sample 103-638B-21R-1, 121-123 cm, contains Cleistosphaeridium ancoriforum sensu Srivastava and Oligosphaeridium verrucosum. C. ancoriforum sensu Srivastava has a basal occurrence in the lower Barremian in southern France (Srivastava, 1984). O. verrucosum has been described from the upper Aptian of DSDP Hole 400A (Davey, 1979b). In Holes $400 \mathrm{~A}$ and $402 \mathrm{~A}$, the first appearance of this characteristic form is reported in a sample dated as late Aptian from foraminifers (Dupeuble, 1979). The first occurrence of $O$. verrucosum in DSDP Hole 398D is correlated with the Hedbergella trocoidea Zone (Sigal, 1979); the last occurrence is in the Aptian (Masure, 1984). In DSDP Hole 545, offshore northwest Africa, Below (1984) observed the first occurrence of $O$. verrucosum in Sample 545-52-2, 123-126 cm, and the last occurrence in Sample 545-47-6, 72-75 cm. Sample 545-52-2, 123$126 \mathrm{~cm}$, is in the $H$. trocoidea Zone, and Sample 545-47-6, $72-75 \mathrm{~cm}$, is correlated with the Globigerinelloides gyroidinaeformis Subzone of the lower Albian (Leckie, 1984). The last occurrence of Druggidium deflandrei is reported to be in the upper Aptian (Habib and Drugg, 1983; Williams and Bujak, 1985). The presence of Druggidium deflandrei and $O$. verrucosum in Sample 103-638B-21R-2, 121-123 cm, suggests that a late Aptian age is more likely for Core 103-638B-21R than an Albian age. 


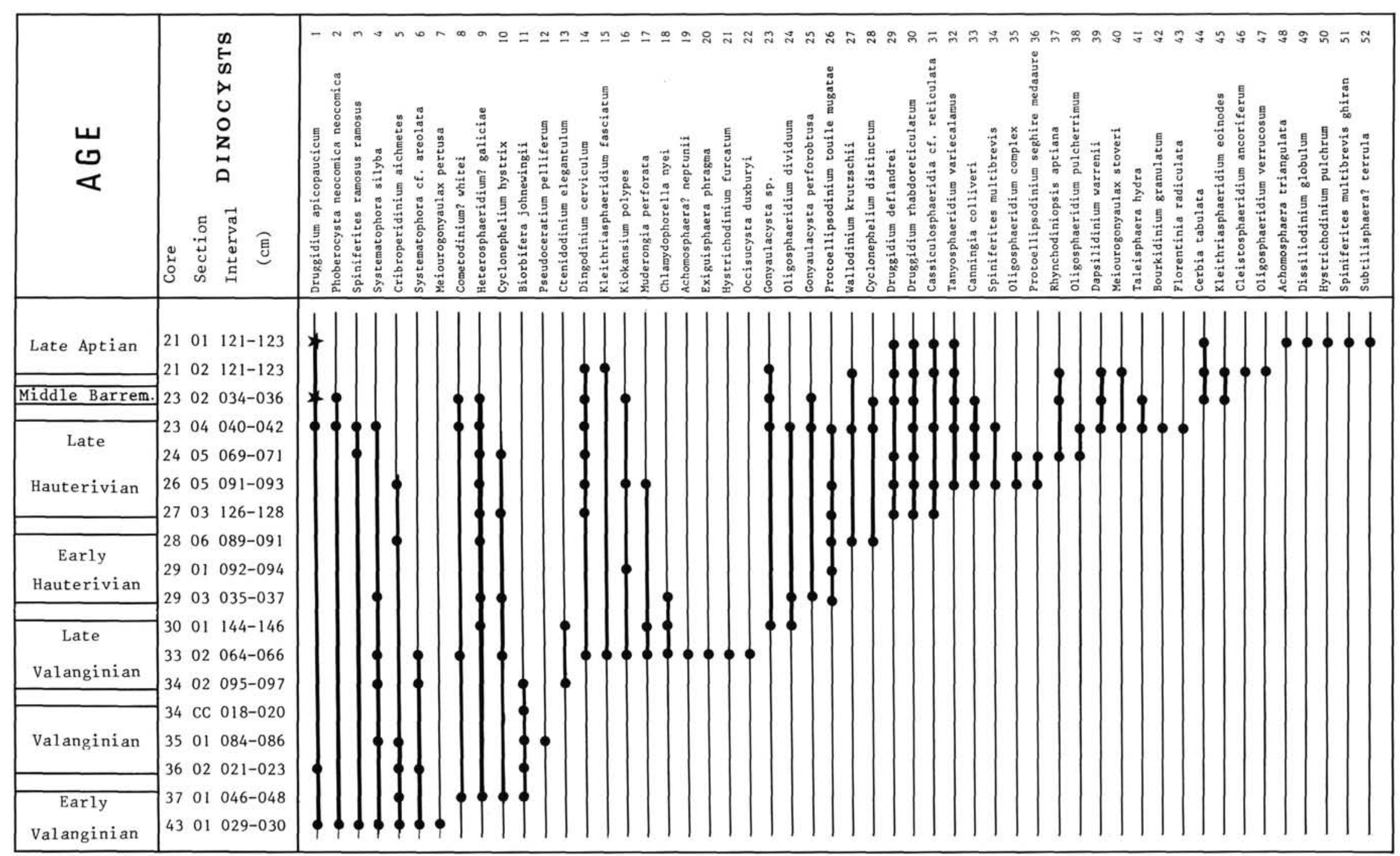

Figure 3. Distribution chart of dinoflagellate cysts of Cretaceous age from Hole 638B. Reworked dinoflagellate cysts are marked by a star. 


\section{CONCLUSIONS}

\section{Site 638}

Dinoflagellate cyst assemblages date the syn-rift sediments (the turbidite sandstone of lithologic Unit III and the claystone and marlstone of lithologic Unit II) of Holes $638 \mathrm{C}$ and $638 \mathrm{~B}$ as follows:

\section{Hole $638 \mathrm{C}$}

Upper Berriasian-lower Valanginian? (58.5 m): Samples 103$638 \mathrm{C}-14 \mathrm{R}-1,128-130 \mathrm{~cm}$, to $103-638 \mathrm{C}-8 \mathrm{R}-1,78-80 \mathrm{~cm}(538.8-$ $480.3 \mathrm{mbsf}$ ).

Lower Valanginian $(40 \mathrm{~m})$ : Samples 103-638C-7R-2, 39-41 $\mathrm{cm}$, to $103-638 \mathrm{C}-3 \mathrm{R}-1,59-61 \mathrm{~cm}(471.8-431.8 \mathrm{mbsf})$.

Sample $103-638 \mathrm{C}-1 \mathrm{R}-2,49-51 \mathrm{~cm}$, is barren.

\section{Hole 638B}

Valanginian $(124.4 \mathrm{~m})$ :

Lower Valanginian-Valanginian (22 m): Samples 103-638B$43 \mathrm{R}-1,29-30 \mathrm{~cm}$, to $103-638 \mathrm{~B}-34 \mathrm{R}$, CC $(18-20 \mathrm{~cm})(402.5-$ 324.5 mbsf).

Upper Valanginian (39.6 m): Samples 103-638B-34R-2, 95$97 \mathrm{~cm}$, to $103-638 \mathrm{~B}-30 \mathrm{R}-1,144-146 \mathrm{~cm}(317.7-278.1 \mathrm{mbsf})$.

Hauterivian $(56 \mathrm{~m})$ :

Lower Hauterivian (13.6 m): Samples 103-638B-29R-3, 35$37 \mathrm{~cm}$, to $103-638 \mathrm{~B}-28 \mathrm{R}-6,89-91 \mathrm{~cm}$ (270.3-265.7 mbsf).

Upper Hauterivian (36.6 m): Samples 103-638B-27R-3, 126$128 \mathrm{~cm}$, to $103-638 \mathrm{~B}-23 \mathrm{R}-4,40-42 \mathrm{~cm}$ (250.8-214.2 mbsf).

Middle Barremian: Sample 103-638B-23R-2, 34-36 cm (211 mbsf).

Upper Aptian (1.5 m): Samples 103-638B-21R-2, 121-123 cm, to $103-638 \mathrm{~B}-21 \mathrm{R}-1,121-123 \mathrm{~cm}$ (192.3-191.3 mbsf).

An unconformity occurs in the lower Barremian, as suggested by Shipboard Scientific Party (1987a). Dinoflagellate cyst assemblages date Core 103-638B-21R as late Aptian; the other microfossils date this core as late Barremian.

Samples 103-638B-23R-2, 34-36 cm, (middle Barremian) and 103-638B-21R-1, 121-123 cm, (Aptian) contain D. apicopaucicum. The last occurrence of D. apicopaucicum is at the top of the Hauterivian Subsaynella sayni ammonite zone (Habib and Drugg, 1983). Material of Valanginian or Hauterivian age is reworked in the Barremian and Aptian sediments.

\section{Site 639}

The eleven samples analyzed from Holes 639A, 639C, and 639D are barren.

\section{Correlation}

Holes $638 \mathrm{~B}$ and $638 \mathrm{C}$ can be correlated by comparing dinoflagellate cyst assemblages and the first occurrences of $D$. apicopaucicum and the $S$. ramosus group. The section from Samples $103-638 \mathrm{C}-7 \mathrm{R}-2,39-41 \mathrm{~cm}$, to $103-638 \mathrm{C}-3 \mathrm{R}-1,59-61 \mathrm{~cm}$, is comparable to the section from Samples 103-638B-43R-1, 29$30 \mathrm{~cm}$, to $103-638 \mathrm{~B}-34 \mathrm{R}, \mathrm{CC}(18-20 \mathrm{~cm})$. The age of this section is early Valanginian-Valanginian.

\section{TAXONOMY}

The following section is divided into two parts. The first part lists, in alphabetical order, all dinoflagellate cysts encountered in this study, with reference to plates and figures and to position in the distribution charts. The first number in parentheses refers to the position of the species in Hole 638B; the second indicates the position of the species in Hole 638C. A zero indicates that the species is absent. The second part describes both new spe- cies and those species that require certain amplifying remarks. New species are housed in the micropaleontological collection (Centre Scientifique G. Deflandre) of the Museum of National History, Paris, France.

\section{TAXA LIST}

Achomosphaera? neptunii (Eisenack, 1958) Davey and Williams, 1966a; Pl. 1, Fig. 1. $(19,6)$

Achomosphaera triangulata (Gerlach, 1961) Davey and Williams, 1969. $(48,0)$

Batioladinium varigranosum (Duxbury, 1977) Davey, 1982; Pl. 1, Fig. 2. $(0,16)$

Batioladinium sp. I in Davey, 1982, p. 22-23, pl. 5, figs. 11-13; Pl. 1, Fig. 3. $(0,17)$

Biorbifera johnewingii Habib, 1972; Pl. 1, Fig. 4. (11, 11)

Bourkidinium granulatum Morgan, 1975; Pl. 1, Fig. 5. (42, 0)

Canningia colliveri Cookson and Eisenack, 1960. $(33,0)$

Cassiculosphaeridia cf. reticulata Davey, 1969; Pl. 1, Fig. 6. (31, 0)

Cerbia tabulata (Davey and Verdier, 1974) Below, 1981a; Pl. 1, Fig. 7. $(44,0)$

Chlamydophorella nyei Cookson and Eisenack, 1958. $(18,0)$

Cleistosphaeridium ancoriferum sensu Srivastava, 1984, p. 27, pl. 6, fig. 1-5; Pl. 1, Fig. 8. (46, 0)

Cometodinium? whitei (Deflandre and Courteville, 1939) Stover and Evitt, 1978. (8, 0)

Cribroperidinium aichmetes (Sarjeant, 1966) Helenes, 1984; Pl. 1, Fig. 9. $(5,0)$

Ctenidodinium elegantulum Millioud, 1969; Pl. 1, Fig. 10. (13, 0)

Cyclonephelium distinctum Deflandre and Cookson, 1955. $(28,0)$

Cyclonephelium hystrix (Eisenack, 1958) Davey, 1978; PI. 1, Fig. 11. $(10,7)$

Dapsilidinium warrenii (Habib, 1976) Lentin and Williams, 1981; Pl. 1, Fig. 12. $(39,8)$

Dingodinium cerviculum Cookson and Eisenack, 1958; PI. 1, Fig. 13. $(14,10)$

Dissiliodinium globulum Drugg, 1978. $(49,0)$

Druggidium apicopaucicum Habib, 1973; Pl. 1, Fig. 14. (1, 12)

Druggidium deflandrei (Millioud, 1969) Habib, 1973; Pl. 1, Fig. 15. $(29,0)$

Druggidium rhabdoreticulatum Habib, 1973; Pl. 1, Fig. 16. $(30,0)$ Exiguisphaera phragma Duxbury, 1979; Pl. 2, Fig. 1. (20, 18)

Florentinia radiculata (Davey and Williams, 1966b) Davey and Verdier, 1973; Pl. 2, Fig. 2. $(43,0)$

Gonyaulacysta? perforobtusa Duxbury, 1977; Pl. 2, Fig. 3. (25, 0)

Gonyaulacysta sp.; Pl. 2, Fig. 4. $(23,15)$

Heterosphaeridium? galiciae n. sp.; Pl. 2, Figs. 5-7. $(9,0)$

Hystrichodinium furcatum Alberti, 1961; Pl. 2, Fig. 8. (21, 0)

Hystrichodinium pulchrum Deflandre, 1935. (50, 0)

Hystrichodinium voigtii (Alberti, 1961) Davey, 1974. $(0,14)$

Kiokansium polypes (Cookson and Eisenack, 1962) Below, 1982b; Pl. 2, Fig. 9. (16, 19)

Kleithriasphaeridium eionodes (Eisenack, 1958) Davey, 1974; Pl. 2, Fig. 10. $(45,0)$

Kleithriasphaeridium fasciatum (Davey and Williams, 1966b) Davey, 1974. $(15,0)$

Meiourogonyaulax pertusa (Duxbury, 1977) Below, 1981a; Pl. 2, Fig. 11. $(7,0)$

Meiourogonyaulax stoveri Millioud, 1969; Pl. 3, Fig. 1. (40, 0)

Muderongia perforata Alberti, 1961; PI. 3, Fig. 2. $(17,0)$

Muderongia simplex subsp. simplex Alberti, 1961. $(0,4)$

Muderongia simplex subsp. microperforata Davey, 1982. $(0,20)$

Occisucysta duxburyi Jan du Chêne et al., 1986a; Pl. 3, Fig. 3. $(22,0)$

Oligosphaeridium complex (White, 1842) Davey and Williams, 1966b. $(35,0)$

Oligosphaeridium dividuum Williams, 1978; Pl. 3, Fig. 4. $(24,0)$

Oligosphaeridium pulcherrimum (Deflandre and Cookson, 1955) Davey and Williams, 1966b. $(38,0)$

Oligosphaeridium verrucosum Davey, 1979b; Pl. 3, Fig. 5. (47, 0)

Phoberocysta neocomica neocomica (Gocht, 1957) Millioud, 1969. (2, 3)

Protoellipsodinium seghire subsp. medaaure Below, 1981a. $(36,0)$

Protoellipsodinium touile subsp. mugatae Below, 1981a; Pl. 3, Fig. 6. $(26,0)$

Pseudoceratium pelliferum Gocht, 1957; Pl. 3, Fig. 7. (12, 2) 
Rhynchodiniopsis aptiana Deflandre, 1935; Pl. 3, Fig. 8. (37, 0)

Rhynchodiniopsis fimbriata (Duxbury, 1980) Sarjeant, 1982; Pl. 3, Fig. 9. $(0,21)$

Spiniferites multibrevis (Davey and Williams, 1966a) Below, 1982b; Pl. 3, Fig. 10. $(34,13)$

Spiniferites multibrevis ghiran Below, 1982b. $(51,0)$

Spiniferites ramosus (Ehrenberg, 1838) Loeblich and Loeblich, 1966. (3, $0)$

Subtilisphaera? terrula (Davey, 1974) Lentin and Williams, 1976; Pl. 3, Fig. 11. $(52,0)$

Systematophora cf. areolota Klement, 1960 in Davey, 1982, pl. 1, fig. 5; Pl. 3, Fig. 12. $(6,1)$

Systematophora silyba Davey, 1979a. $(4,0)$

Systematophora sp. II in Davey, 1982, pl. 1, figs. 10 and 11. $(0,5)$

Taleisphaera hydra Duxbury, 1979; Pl. 3, Fig. 13. (41, 0)

Tanyosphaeridium magneticum Davies, 1983. $(0,9)$

Tanyosphaeridium variecalamus Davey and Williams, 1966b. $(32,0)$

Tehamadinium dodekovae Jan du Chêne et al., 1986a; Pl. 3, Fig. 14. (0, 22)

Wallodinium krutzschii (Alberti, 1961) Habib, 1972; Pl. 3, Fig. 15. (27, 0)

\section{DESCRIPTION}

Class DINOPHYCEAE Fritsch, 1929

Order PERIDINIALES Haeckel, 1894 Genus CLEISTOSPHAERIDIUM Davey et al., 1966

Type species Cleistosphaeridium diversispinosum Davey et al., 1966, p. 167 , pl. 10, fig. 7

\section{Cleistosphaeridium ancoriferum sensu Srivastava, 1984}

$$
\text { (Pl. 1, Fig. 8) }
$$

Description. This proximochorate and holocavate dinoflagellate cyst has a subspheroidal central body. Autophragm is smooth with numerous nontabular processes, of large breadth and uniform height, and covered by a thin ectophragm that is interrupted in places. The archeopyle indicates gonyaulacoid paratabulation. Archeopyle is $4 \mathrm{~A}$ or $(4 \mathrm{~A})$, and the operculum is free.

Comparison. The large and hollow processes exhibited by Cleistosphaeridium ancoriferum sensu Srivastava differentiate it from Cleistosphaeridium ancoriferum. Cleistosphaeridium ancoriferum has thin processes that are mainly solid, closed distally, and not covered by an ectophragm.

Dimensions. Five specimens were measured. Central body: diameter 28(31)34.5 $\mu \mathrm{m}$. Processes: length 5.5(8)9.5 $\mu \mathrm{m}$ and breadth $1.5(2) 2.5$ $\mu \mathrm{m}$.

Occurrences. Cleistosphaeridium ancoriferum sensu Srivastava occurs in Aptian sediment in ODP Hole 638B, Sample 103-638B-21R-2, 121-123 cm (No. 46, Fig. 3).

Genus GONYAULACYSTA Deflandre, 1964, p. 5030; emend.

Sarjeant, 1969, p. 7-8; emend. Stover and Evitt, 1978, p. 157-158; emend. Sarjeant, 1982 , p. $27-28$

Type species Gonyaulacysta jurassica (Deflandre, 1938, p. 168, figs. 1 and 2 and pl. 6, figs. 2-5) Norris and Sarjeant, 1965, p. 65; emend. Sarjeant, 1982 , p. $28-30$

\section{Gonyaulacysta sp. \\ (Pl. 2, Figs. 4A-4C)}

Description. This is a proximate two-layered dinoflagellate cyst with a subspheroidal central body. The cyst is slightly suturocate with reduced epipericoel and without hypopericoel. Parasutural septa irregularly perforate or punctate, with a denticulate distal margin. A row of perforations is at the foot of the septa. Intratabular area is smooth. Paratabulation gonyaulacoid: ?2 preapicals, 4 apicals, 6 precingulars, $X$ cingulars, 5 postcingulars, 1 posterior intercalary, 1 antapical, $\mathrm{X}$ sulcals. Precingular archeopyle is type P 4, according to the Taylor Evitt system; operculum is free.

Comparison. Gonyaulacysta sp. differs from Gonyaulacysta exsanguia Duxbury, 1977 by the microperforate septa that have slightly denticulate distal crests. Gonyaulacysta diutina Duxbury, 1977 has denticulate distal crests and tubercules in the intratabular areas.

Dimensions. Length: 53(58)62 $\mu \mathrm{m}$. Breadth: $54(56) 61 \mu \mathrm{m}$. Septa height: 5-7 $\mu \mathrm{m}$. Central body length: $43(45) 49 \mu \mathrm{m}$. Central body breadth:
42(44)48 $\mu \mathrm{m}$. Apical horn: 4-7 $\mu \mathrm{m}$. Five well-oriented individuals were measured.

Occurrences. Gonyaulacysta sp. occurs in upper Valanginian through Aptian sediment in Hole 638B, Samples 103-638B-30R-1, 144$146 \mathrm{~cm}$, to 103-638B-21R-2, 121-123 cm, (No. 23, Fig. 3) and in lower Valanginian sediment in Hole 638C, Sample 103-638C-6R-2, 69-71 cm (No. 15, Fig. 2).

Genus HETEROSPHAERIDIUM Cookson and Eisenack, 1968; emend. Yun, 1981

Type species Heterosphaeridium conjunctum Cookson and Eisenack, 1968 , p. 115 , figs. $4 \mathrm{G}$ and $4 \mathrm{H}$

Heterosphaeridium? galiciae n. sp. (Pl. 2, Figs. 5A-5C, $6 \mathrm{~A}, 6 \mathrm{~B}$, and 7)

Derivation of name. The name is derived from Galicia Bank, the location of Site 638, ODP Leg 103.

Diagnosis. This proximochorate two-layered dinoflagellate cyst has a subspheroidal central body. Periphragm and endophragm are appressed between processes. The intratabular hollow processes have broad bases and gradually taper to the tips, which display a truncated distal margin. Gonyaulacoid paratabulation: 4 apicals, 6 precingulars, $X$ cingulars, 5-6 postcingulars, ? 1 posterior intercalary, 1 antapical, and $X$ sulcals. Apical archeopyle is (4A) or $4 \mathrm{~A}$, with accessory sutures between the precingular paraplates. The operculum is free.

Description. Subspheroidal lightly-pitted central body has a sulcal notch that is not displaced to the left. The two layers are closely appressed except were the periphragm forms the processes. Intratabular processes are simple or branched and slightly costulate. They are not reduced in size on the ventral face. The hollow processes usually branch medially to give rise to two or four main branches, and these may give rise to further short branches that are truncated distally. Accessory archeopyle sutures are developed between the precingular paraplates.

Comparison. The ? is introduced in naming because of the uncertain shape of the central body in the diagnosis of the genus Heterosphaeridium, because of the processes of Heterosphaeridium? galiciae are hollow. Processes of the other species are hollow and solid.

Dimensions. Holotype: Total length: $60 \mu \mathrm{m}$. Central body: length 42 $\mu \mathrm{m}$. Central body breadth: $47 \mu \mathrm{m}$. Processes: length $18 \mu \mathrm{m}$, basal breadth 2 and $3 \mu \mathrm{m}$, and distal breadth 0.5 and $1 \mu \mathrm{m}$. Six well-oriented individuals without the operculum: Length: $67(64) 60 \mu \mathrm{m}$. Central body length: $52(48) 42 \mu \mathrm{m}$. Central body breadth: $52(50) 47 \mu \mathrm{m}$. Processes: length: 18(16) $14 \mu \mathrm{m}$, basal breadth: 2 and $3 \mu \mathrm{m}$, distal breadth: 0.5 and $1 \mu \mathrm{m}$. Individual with operculum, one specimen: Diameter: $56 \mu \mathrm{m}$.

Occurrences. Heterosphaeridium? galiciae occurs in Valanginian through Barremiam sediment in ODP Hole 638B, from Samples 103638B-37R-1, 46-48 cm, to 103-638B-23R-2, 34-36 cm (No. 9, Fig. 3).

Holotype. Slide 1: Y 49-50, Sample 103-638B-23R-4, 40-42 cm (Pl. 2, Fig. 5)

Type locality. Heterosphaeridium? galiciae n. sp. was found at Site 638 of ODP Leg 103, on the southwest edge of the Galicia Bank, offshore Spain.

Type horizon. Late Hauterivian.

Depth. 214.2 mbsf.

\section{ACKNOWLEDGMENTS}

The author wishes to thank the staff of Ocean Drilling Program for making material available. I also express my appreciation to J. Taugourdeau-Lantz, to C.N.R.S. "soutien" ODP France for providing financial support, to U.A.-C.N.R.S. 319, and to "le laboratoire de Micropaléontologie" for providing work facilities. The help of W. S. Drugg, D. Habib, and A. W. Meyer is acknowledged with thanks for reviewing the manuscript.

\section{REFERENCES}

Alberti, G., 1961. Zur Kenntnis mesozoischer und alt-tertiarer Dinoflagellaten und Hystrichosphaerideen von Nord-und Mitteldeutschland sowie einigen anderen europäischen Gebieten. Palaeontographica Ser. A, 116:1-58.

Below, R., 1981a. Dinoflagellaten-Zysten aus dem oberen Hauterive bis unteren Cenoman Süd-West-Marokkos. Palaeontographica, Ser. B, 176:1-145. 
1981b. Dinoflagellaten-Zysten aus dem Platylenticeras-Schichten (unteres Mittel-Valendis) der Ziegeleitongrube Schnepper in Suddendorf/Nordwest-Deutschland. Newsl. Stratigr., 10:115-125.

1982a. Dinoflagellate cysts from Valanginian to lower Hauterivian sections near Ait Hamouch, Morocco. Rev. Esp. Micropaleontol., 14:23-52.

1982b. Scolochorate Zysten der Gonyaulacaceae (Dinophyceae) aus der Unterkreide Marokkos. Palaeontographica, Ser. B, $182: 1-51$.

1984. Aptian to Cenomanian dinoflagellate cysts from Mazagan Plateau, northwest Africa (Sites 545 and 547, Deep Sea Drilling Project Leg 79). In Hinz, K., Winterer, E. L., et al., Init. Repts. DSDP, 79: Washington (U.S. Govt. Printing Office), 621-649.

Boillot, G., Winterer, E. L., et al., 1987. Proc. ODP, Init. Repts., 103: College Station, TX (Ocean Drilling Program).

Cookson, I. C., and Eisenack, A., 1958. Microplankton from Australian and New Guinea Upper Mesozoic sediments. Proc. R. Soc. Victoria, 70:19-79.

1960. Upper Mesozoic microplankton from Australia and New Guinea. Palaeontology, 2: 243-261.

1962. Additional microplankton from Australian Cretaceous sediments. Micropaleontology, 8:485-507.

1968. Microplankton from two samples from Gingin Brook no. 4 borehole, western Australia. J. R. Soc. West. Aust., 51:110122.

Davey, R. J., 1969. Non-calcareous microplankton from the Cenomanian of England, northern France and North America, Part I. Bull. Brit. Mus. Nat. Hist. Geol., 17:1-11.

1974. Dinoflagellate cysts from the Barremian of the Speeton Clay, England. In Symposium on Stratigraphic Palynology: Spec. Publ. Birbal Sahni Inst. Palaeobot., 3:41-75.

1978. Marine Cretaceous palynology of Site 361, DSDP Leg 40, off Southwest Africa. In Bolli, H. M., Ryan, W.B.F., et al., Init. Repts. DSDP, 40: Washington (U.S. Govt. Printing Office), 883913.

1979a. Two new Early Cretaceous dinocyst species from the northern North Sea. Palaeontology, 22:427-437.

1979b. Marine Apto-Albian palynomorphs from Holes 400A and 402A, IPOD Leg 48, northern Bay of Biscay. In Montadert, L., Roberts, D. G., et al., Init. Repts. DSDP, 48: Washington (U.S. Govt. Printing Office), 547-577.

1979c. The stratigraphic distribution of dinocysts in the Portlandian (latest Jurassic) to Barremian (Early Cretaceous) of northwest Europe. Contrib. Am. Assoc. Stratigr. Palynol., 5B:48-81.

1982. Dinocyst stratigraphy of the latest Jurassic to Early Cretaceous of the Haldager no. 1 borehole, Denmark. Dan. Geol. Unders. Raekke B, 6:1-57.

Davey, R. J., Downie, C., Sarjeant, W.A.S., and Williams, G. L., 1966. Fossil dinoflagellate cysts attributed to Baltisphaeridium. Bull. Brit. Mus. Nat. Hist. Geol. Suppl., 3:157-175.

Davey, R. J., and Verdier, J.-P., 1973. An investigation of microplankton assemblages from latest Albian (Vraconian) sediments. Rev. Esp. Micropaleontol., 5: 173-212.

1974. Dinoflagellate cysts from the Aptian type sections at Gargas and La Bédoule, France. Palaeontology, 17:623-653.

Davey, R. J., and Williams, R. J., 1966a. The genera Hystrichosphaera and Achomosphaera. Bull. Brit. Mus. Nat. Hist. Geol. Suppl., 3: 28-52.

1966b. The genus Hystrichosphaeridium and its allies. Bull. Brit. Mus. Nat. Hist. Geol. Suppl., 3:53-106.

1969. Generic reallocations. Bull. Brit. Mus. Nat. Hist. Geol. Append. Suppl., 3:4-7.

Davies, E. H., 1983. The dinoflagellate Oppel-zonations of the Jurassic-Lower Cretaceous sequences in the Sverdrup Basin, Arctic Canada. Bull. Geol. Surv. Canada, 359:1-59.

Deflandre, G., 1935. Considérations biologiques sur les microorganismes d'origine plantonique conservés dans les silex de la craie. Bull. Biol. Fr. Belg., 69:213-244.

1938. Microplancton des mers jurassiques conservé dans les marnes de Villers-sur-Mer (Calvados). Etude liminaire et considérations générales. Trav. Stn. Zool. Wimereux, 13:147-200.

1964. Remarques sur la classification des Dinoflagellés fossiles, á propos d'Evittodinium, nouveau genre crétacé de la famille des Deflandreaceae. C. R. Acad. Sci. Ser. 2, 258:5027-5030.
Deflandre, G., and Cookson, I. C., 1955. Fossil microplankton from Australian Late Mesozoic and Tertiary sediments. Aust. J. Mar. Freshwater Res., 6:242-313.

Deflandre, G., and Courteville, E., 1939. Note préliminaire sur les microfossiles des silex crétacés de Cambrésis. Bull. Soc. Fr. Microsc., 8:95-106.

Drugg, W. S., 1978. Some Jurassic dinoflagellate cysts from England, France and Germany. Palaeontographica, Ser. B, 168:61-79.

Dupeuble, P. A., 1979. Mesozoic foraminifers and microfacies from Holes 400A, 401 and 402A of DSDP Leg 48. In Montadert, L., Roberts, D. G., et al., Init. Repts. DSDP, 48: Washington (U.S. Govt. Printing Office), 451-474.

Duxbury, S., 1977. A palynostratigraphy of the Berriasian of the Speeton Clay of Speeton, England. Palaeontographica, Ser. B, 160:17-67. 1979. Three new genera of dinoflagellate cysts from the Speeton Clay (Early Cretaceous) of Speeton, England. Micropaleontology, 25:198-205.

1980. Barremian phytoplankton from Speeton, east Yorkshire. Palaeontographica, Ser. B, 173:107-146.

1983. A study of dinoflagellate cysts and acritarchs from the Lower Greensand (Aptian to lower Albian) of the Isle of Wight, southern England. Palaeontographica, Ser. B, 186:18-80.

Ehrenberg, C. G., 1838. Uber das Massenverhältniss der jetzt lebenden Kiesel-Infusorien und über ein neues Infusorien-Conglomerat als Polirschiefer von Jastraba in Ungarn. Abh. Preuss. Akad. Wiss., 1836:109-135.

Eisenack, A. 1958. Mikroplankton aus dem norddeutschen Apt. $N$. Jahrb. Geol. Paleontol. Abh., 106:383-422.

Gerlach, E. 1961. Mikrofossilien aus dem Oligozän und Miozän Nordwestdeutschlands, unter besonderer Berücksichtigung der Hystrichosphaeren und Dinoflagellaten. N. Jahrb. Geol. Paleontol. Abh., 112:143-228.

Gocht, H., 1957. Mikroplankton aus dem nordwestdeutschen Neokom (Teil I). Palaeontol. Zeit., 31:163-185.

Habib, D., 1972. Dinoflagellate stratigraphy Leg 11, Deep Sea Drilling Project. In Hollister, C. D., Ewing, J. I., et al., Init. Repts. DSDP, 11: Washington (U.S. Govt. Printing Office), 367-392.

1973. Taxonomy, morphology and suggested phylogeny of the dinoflagellate genus Druggidium. Geosci. Man, 7:47-55. 1977. Comparison of Lower and middle Cretaceous palynostratigraphic zonations in the western North Atlantic. In Swain, F. W. (Ed.), Stratigraphic Micropaleontology of Atlantic Basin and Borderlands: Amsterdam (Elsevier), 887-897.

1978. Palynostratigraphy of the Lower Cretaceous section at Deep Sea Drilling Project Site 391, Blake-Bahama Basin, and its correlation in the North Atlantic. In Benson, W. E., Sheridan, R. E., et al., Init. Repts. DSDP, 44: Washington (U.S. Govt. Printing Office), 887-897.

Habib, D., and Drugg, W. S., 1983. Dinoflagellate age of Middle Jurassic-Early Cretaceous sediments in the Blake-Bahama Basin. In Sheridan, R. E., Gradstein, F. M., et al., Init. Repts. DSDP, 76: Washington (U.S. Govt. Printing Office), 623-638.

1987. Palynology of Sites 603 and 605, Leg 93, Deep Sea Drilling Project. In van Hinte, J. E., Wise, S. W., Jr., et al., Init. Repts. DSDP, 93: Washington (U.S. Govt. Printing Office), 751775 .

Helenes, J., 1984. Morphological analysis of Mesozoic-Cenozoic Cribroperidinium (Dinophyceae), and taxonomic implications. Palynology, 8:107-137.

Jan du Chêne, R., Becheler, I., Helenes, J., and Masure, E. 1986a. Les genres Diacanthum, Exiguisphaera, Occisucysta et Tehamadinium gen. nov. (kystes fossiles de Dinoflagellés). Cah. Micropaleontol., 1(3-4):5-66.

Jan du Chêne, R., Masure, E., Becheler, I., Biffi, U., De Vains, G., Fauconnier, D., Ferrario, R., Foucher, J.-C., Gaillard, M., Hochuli, P., Lachkar, G., Michoux, D., Monteil, E., Moron, J.-M., Rauscher, R., Raynaud, J.-F., Taugourdeau, J., and Turon, J.-L. 1986b. Guide pratique pour la détermination de kystes de Dinoflagellés fossiles: le complexe Gonyaulacysta. Bull. Cent. Rech. Explor. Prod. Elf Aquitaine, 12:1-479.

Jardiné, S., Raynaud, J.-F., and de Renéville, P., 1984. Dinoflagellés, spores et pollens. Crétacé inférieur. In Debrand-Passard, S., Courbouleix, S., Lienhardt, M.-J. (Eds.), Synthèse géologique du SudEst de la France: Mem. BRGM, 125:300-303. 
Klement, K. W., 1960. Dinoflagellaten und Hystrichosphaerideen aus. dem unteren und mittleren Malm Südwestdeutschlands. Palaeontographica, Ser. A, 114:1-104.

Leckie, R. M., 1984. Mid-Cretaceous planktonic foraminiferal biostratigraphy off central Morocco, Deep Sea Drilling Project Leg 79, Sites 545-547. In Hinz, K., Winterer, E. L., et al., Init. Repts. DSDP, 79: Washington (U.S. Govt. Printing Office), 579-620.

Lentin, J. K., and Williams, G. L., 1976. A monograph of fossil peridinoid dinoflagellate cysts. Rep. Bedford Inst. Oceanogr., 75(16):1237.

1981. Fossil dinoflagellates: index to genera and species (1981 ed.). Rep. Bedford Inst. Oceanogr., 81(12):1-345.

, 1985. Fossil dinoflagellates index to genera and species (1985 ed.). Tech. Rep. Can. Hydrogr. Ocean Sci., 60.

Loeblich, A. R., Jr., and Loeblich, A. R., III, 1966. Index to the genera and subgenera, and sections of the Pyrrhophyta. Stud. Trop. Oceanogr., 3.

Masure, E., 1984. L'indice de diversité et les dominances des "communautés" de kystes de Dinoflagellés: marqueurs bathymétriques, forage 398D, croisière 47B. Bull. Soc. Geol. Fr., 26:93-111.

Millioud, M. E., 1967. Palynological study of the localities at Valangin and Hauterive. Rev. Paleobot. Palynol., 5:155-167.

1969. Dinoflagellates and acritarchs from some western European Lower Cretaceous type localities. In Bronnimann, P., and Renz, H. H. (Eds.), Proc. First Int. Conf. Plankt. Microfossils: Leiden (E. J. Brill), 2:420-434.

Monteil, E., 1985. Les dinokystes du Valanginian du Bassin du Sud Est (Ardéche, France). Sci. Terre Mem., 46:1-314.

Morgan, R., 1975. Some Early Cretaceous organic-walled microplankton from the Great Australian Basin, Australia. J. Proc. R. Soc. N. S. W. 108:157-167.

Norris, G., and Sarjeant, W.A.S., 1965. A descriptive index of genera of fossil Dinophyceae and Acritarcha. Bull. N. Z. Geol. Surv., 40:172.

Sarjeant, W.A.S., 1966. Dinoflagellate cysts with Gonyaulax-type tabulation. Bull. Brit. Nat. Hist. Geol. Suppl., 3:107-156.

1969. Taxonomic changes. Appendix to "Studies on Mesozoic and Cenozoic dinoflagellate cysts." Bull. Brit. Mus. Nat. Hist. Geol. Suppl., 3:7-15.
1982. The dinoflagellate cysts of Gonyaulacysta group: a morphological and taxonomic study. Contrib. Am. Assoc. Stratigr. Palynol., 9:1-80.

Shipboard Scientific Party, 1987a. Site 638. In Boillot, G., Winterer, E. L., et al., Proc. ODP, Init. Repts., 103: College Station, TX (Ocean Drilling Program), 221-407.

1987b. Site 639. In Boillot, G., Winterer, E. L., et al., Proc ODP, Init. Repts., 103: College Station, TX (Ocean Drilling Program), 409-532.

Sigal, J., 1979. Chronostratigraphy and ecostratigraphy of Cretaceous formations recovered on DSDP Leg 47B, Site 398. In Sibuet, J.-C., and Ryan, W.B.F., et al., Init. Repts. DSDP, 47, Pt. 1: Washington (U.S. Govt. Printing Office), 287-326.

Srivastava, S. K., 1984. Barremian dinoflagellate cysts from southeastern France. Cah. Micropaleontol., 2:1-39.

Stover, L. E., and Evitt, W. R., 1978. Analyses of pre-Pleistocene, organic-walled dinoflagellates. Stanford Univ. Publ. Geol. Sci., 15:1300 .

White, H. H., 1842. On fossil Xanthidia. Microscope, 11:5-40.

Williams, G. L., 1975. Dinoflagellate and spore stratigraphy of the Mesozoic-Cenozoic, offshore eastern Canada. Pap. Geol. Surv. Can., 30:107-161.

1978. Palynological biostratigraphy, Deep Sea Drilling Project, Sites 367 and 370, Leg 41. In Lancelot, Y., Seibold, E., et al., Init. Repts. DSDP, Suppl. to Vols. 38, 39, 40, and 41: Washington (U.S. Govt. Printing Office), 783-815.

Williams, G. L., and Bujak, J. P., 1985. Palynological stratigraphy of Deep Sea Drilling Project Site 416. In Lancelot, Y., Winterer, E. L., et al., Init. Repts. DSDP, 50: (U.S. Govt. Printing Office), 467-495.

Yun, H.-S., 1981. Dinoflagellaten aus der Oberkreide (Santon) von Westfalen. Palaeontographica, Ser. B, 177:1-89.

Date of initial receipt: 8 April 1987

Date of acceptance: 10 August 1987

Ms 103B-183 


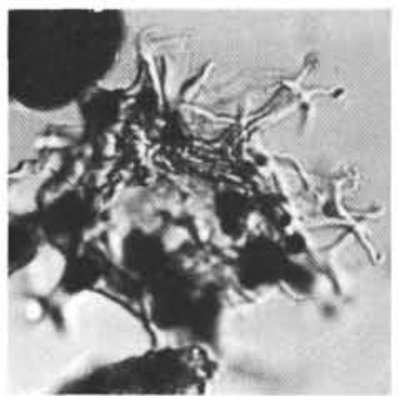

1
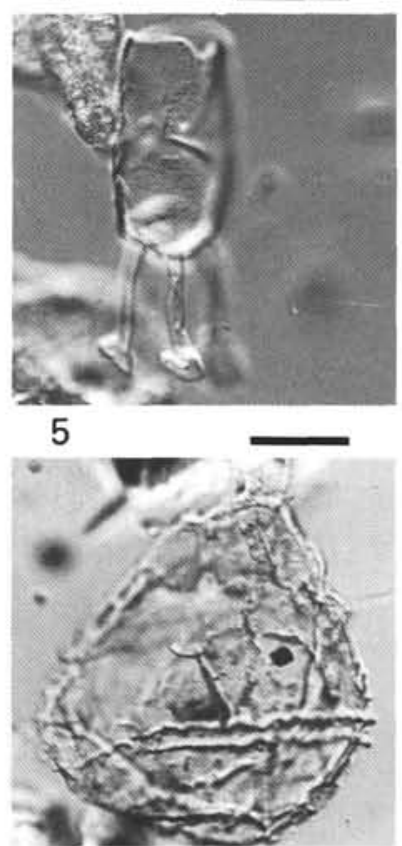

9

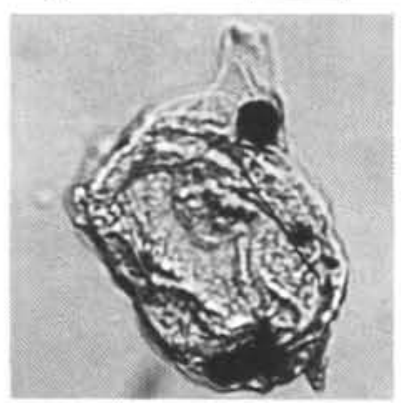

13

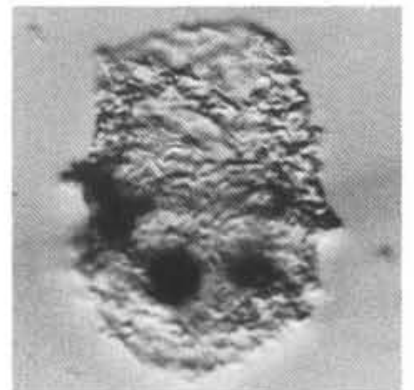

2

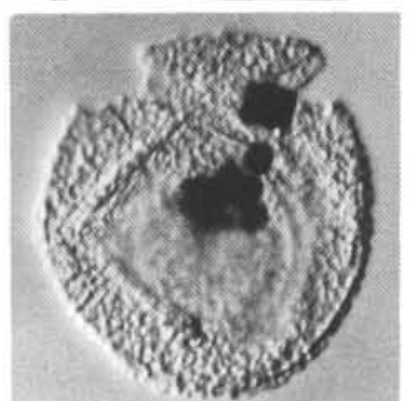

6

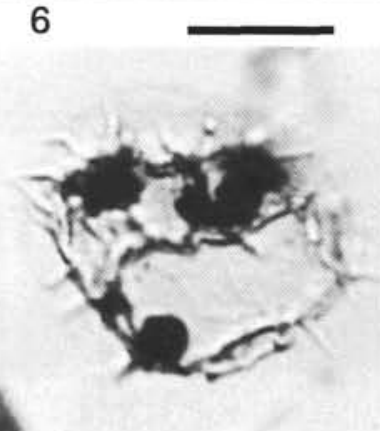

10

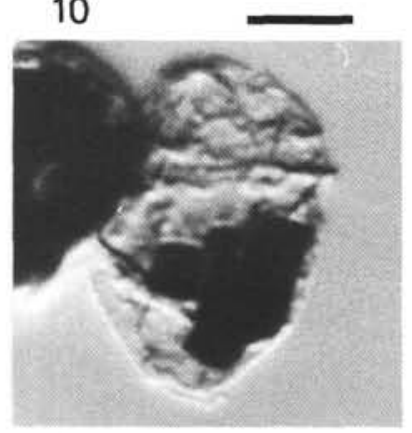

14

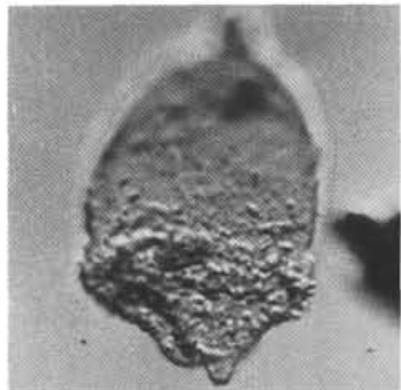

3

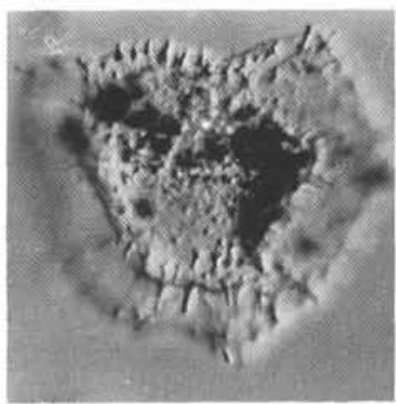

7

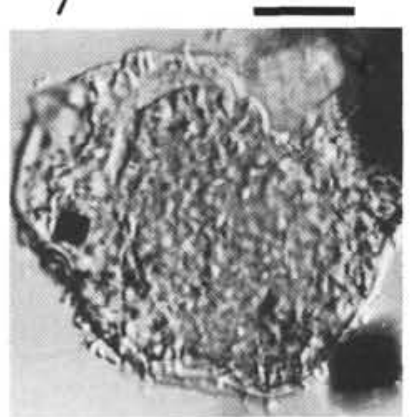

11

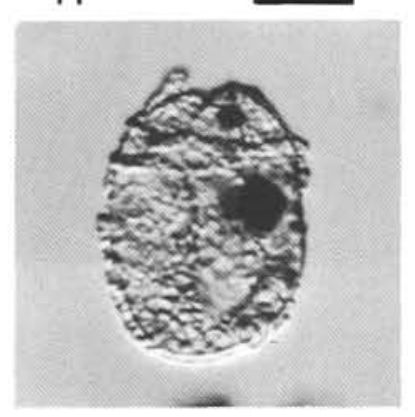

15

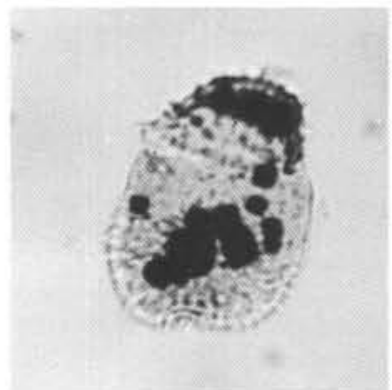

4
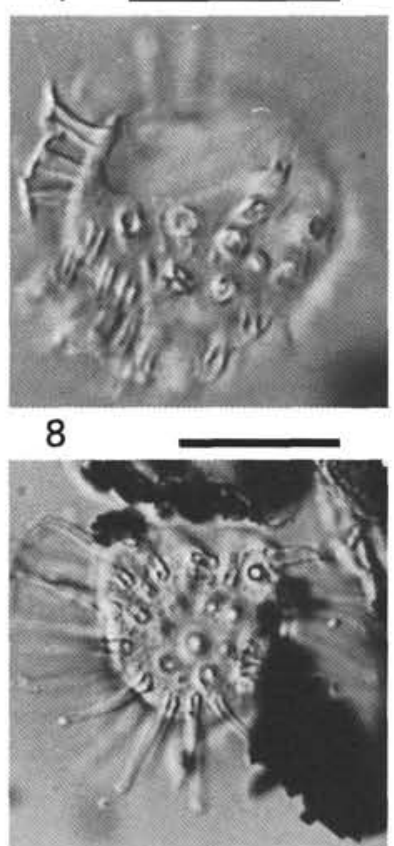

12

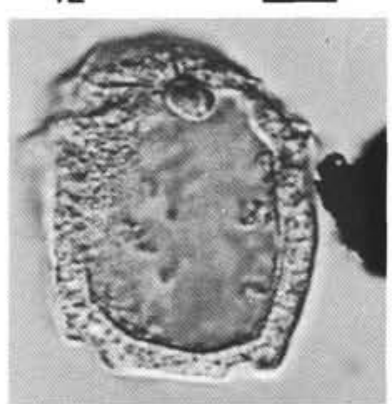

16

Plate 1. Photomicrographs of dinoflagellate cysts. Scale bar $=20 \mu \mathrm{m} .{ }^{*}=$ England finder graticule, coordinate. 1. Achomosphaera? neptunii, Sample 103-638C-14R-1, 128-130 cm. Note pyrite microcrystals. Length $72 \mu \mathrm{m}$, slide 2: O $27^{\circ}$. 2. Batioladinium varigranosum, Sample 103-638C3R-3, 41-43 cm. Length $51 \mu \mathrm{m}$, slide 1: L 33. 3. Batioladinium sp. I in Davey, 1982, Sample 103-638C-3R-3, 41-43 cm. Length $60 \mu \mathrm{m}$, slide 1: E 2627. 4. Biorbifera johnewingii, Sample 103-638C-7R-2, 39-41 cm. Length $29 \mu \mathrm{m}$, slide 3: ST 37-38. 5. Bourkidinium granulosum, Sample 103638B-23R-4, 40-42 cm. Length $64 \mu \mathrm{m}$, slide 1: T 37. 6. Cassiculosphaeridia cf. reticulata, Sample 103-638B-23R-2, 34-36 cm. Length 57 $\mu$ m, slide 1: VW 47. 7. Cerbia tabulata, Sample 103-638B-23R-2, 34-36 cm. Low focus ventral face; length $64 \mu \mathrm{m}$, slide 2: R 43. 8. Cleistosphaeridium ancoriforum sensu Srivastava, Sample 103-638B-21R-2, 121-123 cm. Note the large hollow processes. Diameter $44 \mu \mathrm{m}$, slide 1: Z 26-27. 9. Cribroperidinium aichmetes, Sample 103-638B-28R-6, 89-91 cm. Length $80 \mu \mathrm{m}$, slide 1: QR 29-30. 10. Ctenidodinium elegantulum, Sample 103-638B34R-2, 95-97 cm. Diameter $58 \mu \mathrm{m}$, slide 2: V 49. 11. Cyclonephelium hystrix, Sample 103-638B-34R-2, $95-97 \mathrm{~cm}$. Length $68 \mu \mathrm{m}$, slide 1: QR 39. 12. Dapsilidinium warrenii, Sample 103-638B-21R-2, 121-123 cm. Length $82 \mu \mathrm{m}$, slide 1: Z 36, 13. Dingodinium cerviculum, Sample 103-638C-3R-1, 59-61 cm. Length $52 \mu \mathrm{m}$, slide 1: F 32. 14. Druggidium apicopaucicum, Sample 103-638B-43R-1, 29-31 cm. Length $31 \mu \mathrm{m}$, slide 1: QR $34-35$. 15. Druggidium deflandrei, Sample 103-638B-23R-2, 34-36 cm. Length $44 \mu \mathrm{m}$, slide 1: L 35 . 16. Druggidium rhabdoreticulatum, Sample 103638B-23R-4, 40-42 cm. Length $30 \mu \mathrm{m}$, slide 1: YZ 37. 


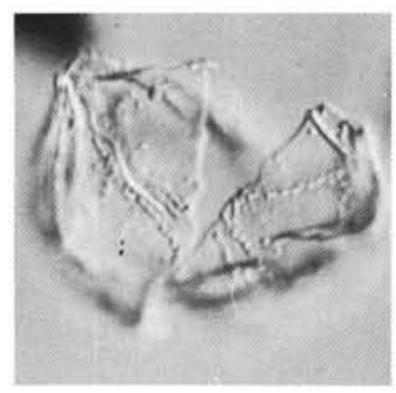

1

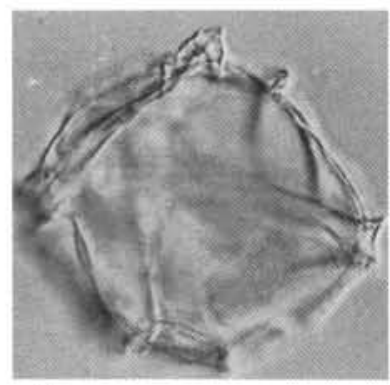

$4 B$

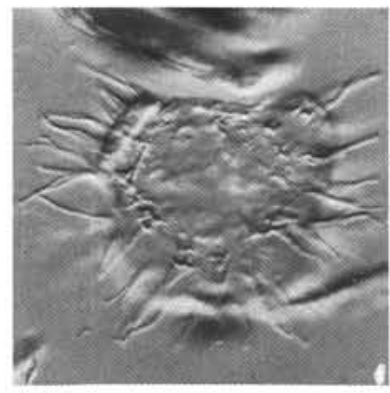

$5 \mathrm{C}$

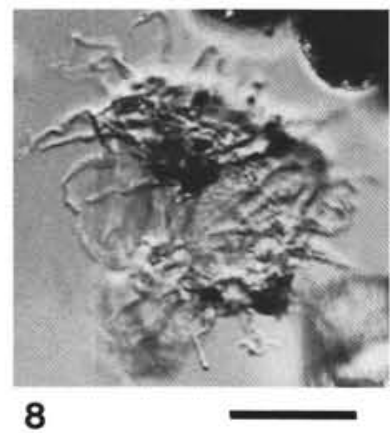

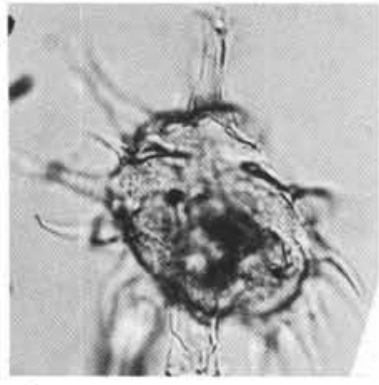

2

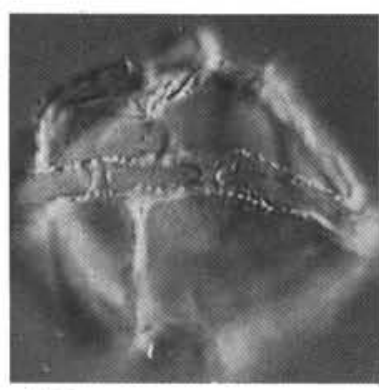

4C

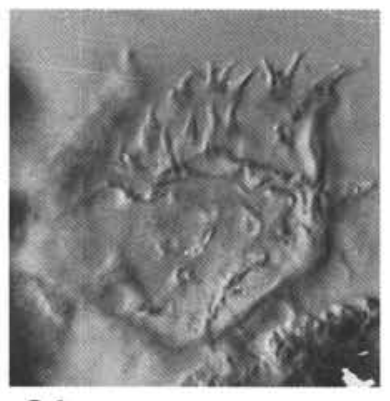

6A

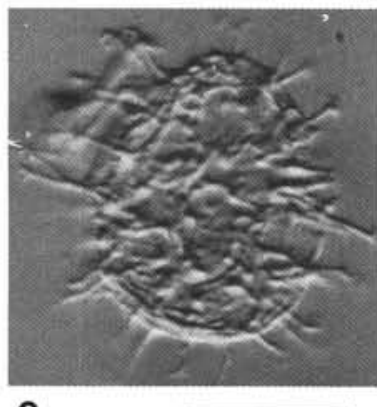

9

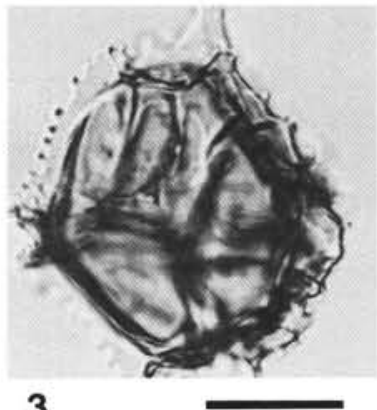

3

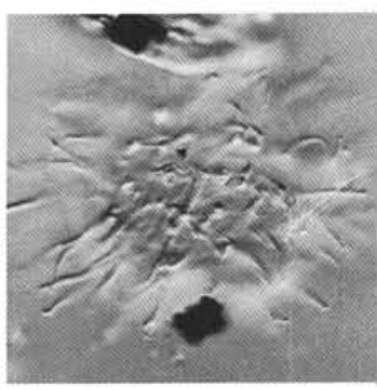

$5 A$

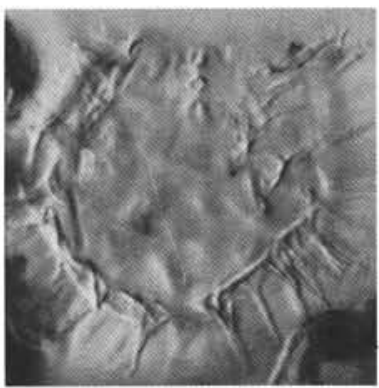

6B

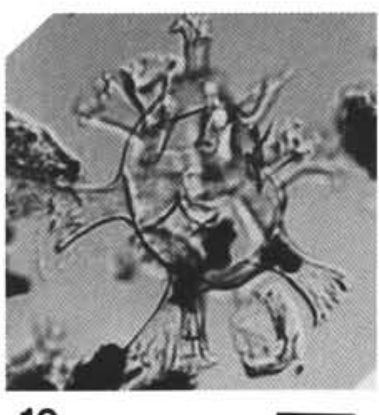

10

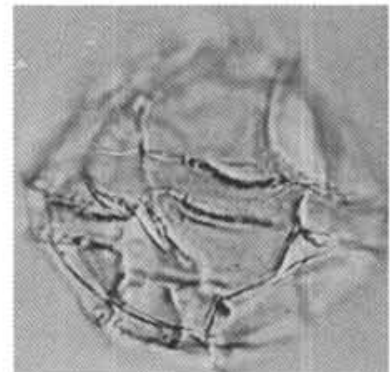

$4 \mathrm{~A}$

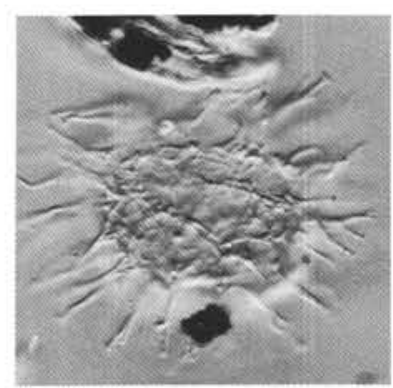

$5 B$

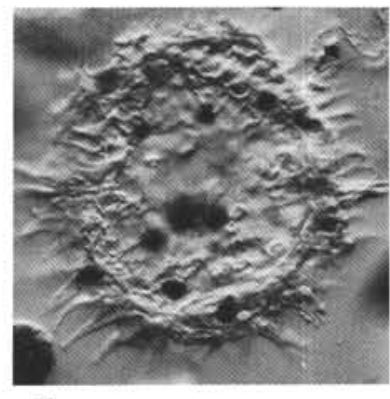

7

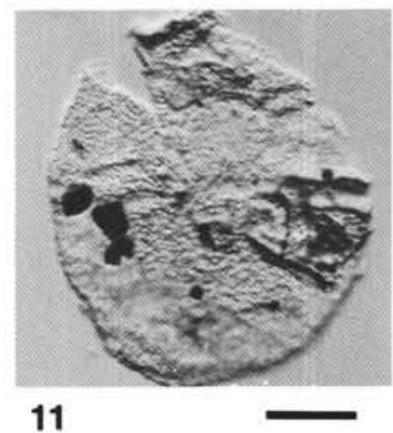

Plate 2. Photomicrographs of dinoflagellate cysts. Scale bar $=20 \mu \mathrm{m}$. 1. Exiguisphaera phragma, Sample 103-638B-33R-2, 64-66 cm. Diameter $48 \mu \mathrm{m}$, slide 1: H 43 . 2. Florentinia radiculata, Sample 103-638B-23R-4, $40-42 \mathrm{~cm}$. Length $76 \mu \mathrm{m}$, slide 1: M $43-44$. 3. Gonyaulacysta? perforobtusa, Sample 103-638B-23R-4, 40-42 cm. Length $56 \mu \mathrm{m}$, width $67 \mu \mathrm{m}$, slide 1: R 37-38. 4. Gonyaulacysta sp., Sample 103-638B-21R-2, 121-123 $\mathrm{cm}$. View of ventral face (A), focus on the apical horn (B), and ventral face at low focus to show the microperforate septa and the small cavations on parasutures (C). Length $56 \mu$ m, slide 1: UV 30. 5. Heterosphaeridium? galiciae n. sp., Sample 103-638B-23R-4, 40-42 cm. Holotype at high focus on dorsal face showing the branched hollow processes truncated distally (A), focus on intratabular hollow processes (B), low focus view of dorsal face (C). Length $60 \mu \mathrm{m}$, slide 1: Y 49-50. 6. Heterosphaeridium? galiciae n. sp., Sample 103-638B-26R-5, 91-93 cm. View of the postcingular hollow processes (A), and focused view on acessory sutures of the archeopyle, showing the row of processes on each precingular paraplate (B). Length $52 \mu \mathrm{m}$, width $49 \mu \mathrm{m}$, processes length $13 \mu \mathrm{m}$, slide 2: T 27. 7. Heterosphaeridium? galiciae $\mathrm{n}$. sp., Sample 103-638C-23R-2, 34-36 cm. Individual with operculum in place; diameter $84 \mu \mathrm{m}$, slide 1: HJ 33-34. 8. Hystrichodinium furcatum, Sample 103-638B-33R-2, 64-66 cm. Specimen folded; length $64 \mu \mathrm{m}$, slide 1: GH 28-29. 9. Kiokansium polypes, Sample 103-638B-33R-2, $64-66 \mathrm{~cm}$. Right paraplate of the operculum displaced; length $44 \mu \mathrm{m}$, slide 1: J 35-36. 10. Kleithriasphaeridium eoinodes, Sample 103-638B-21R-2, 121-123 cm. Left lateral side view; length $94 \mu \mathrm{m}$, slide 1: UV 30. 11. Meiourogonyaulax pertusa, Sample 103-638B-43R-1, 29-31 cm. Dorsal face at low focus; length $88 \mu \mathrm{m}$, slide 1: N 49 . 


\section{E. MASURE}

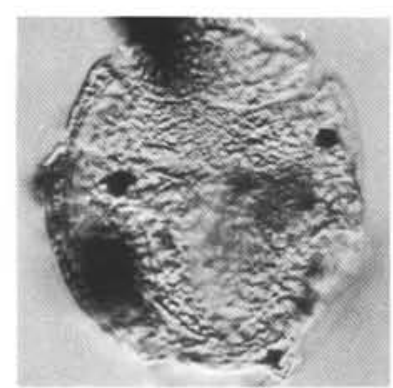

1

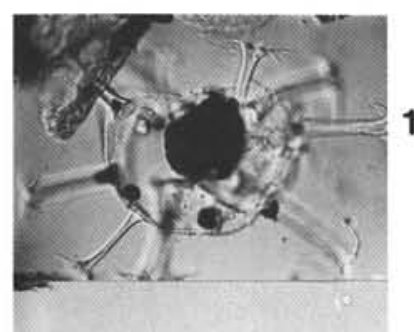

5

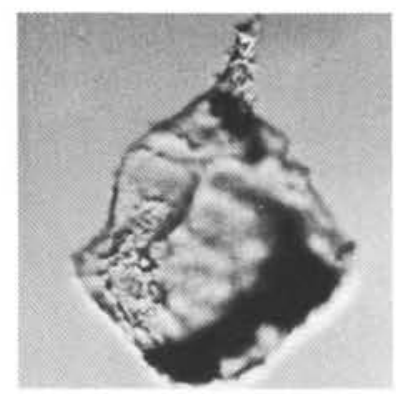

9

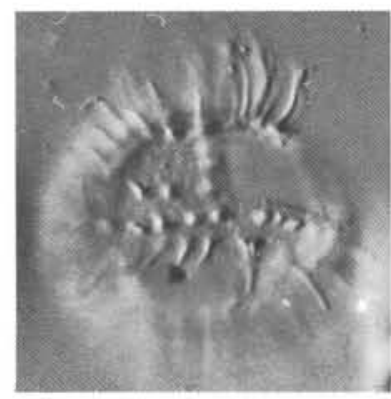

13

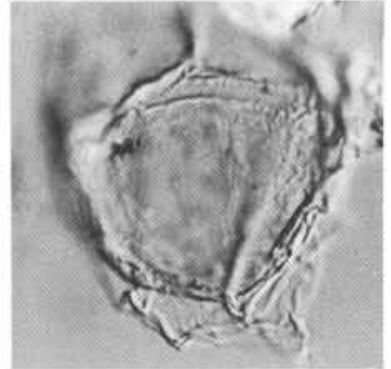

2

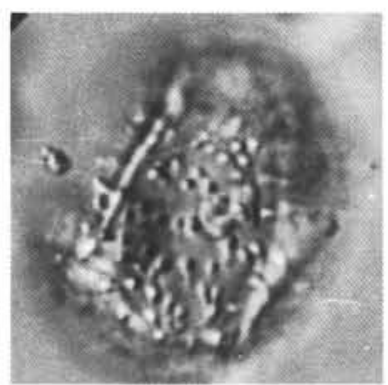

6

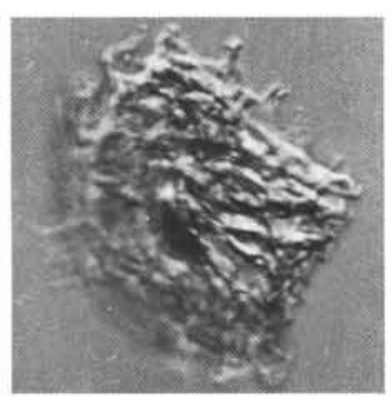

10

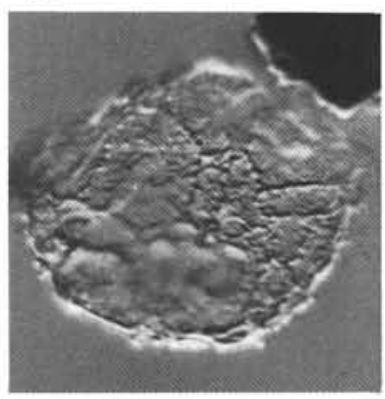

$14 \mathrm{~A}$

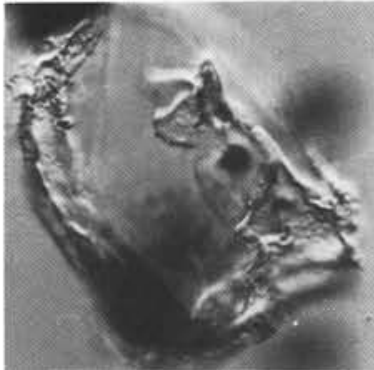

3

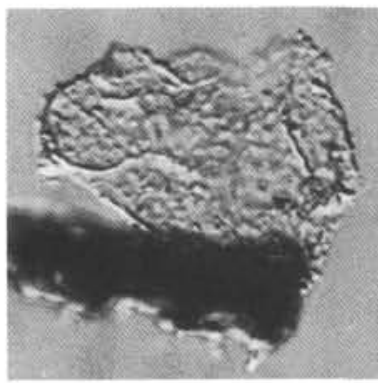

7

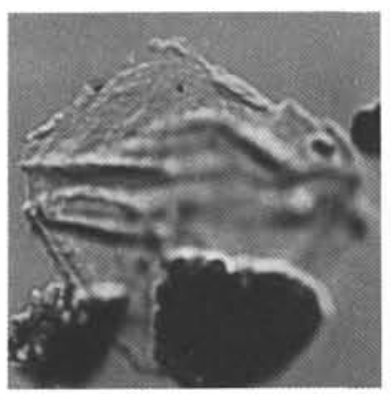

11

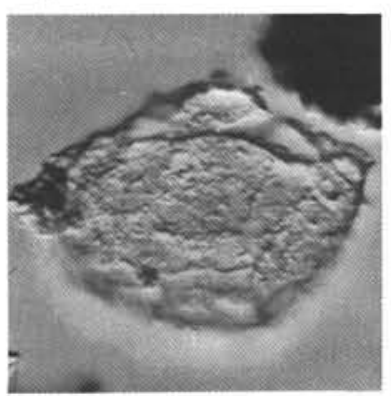

14B

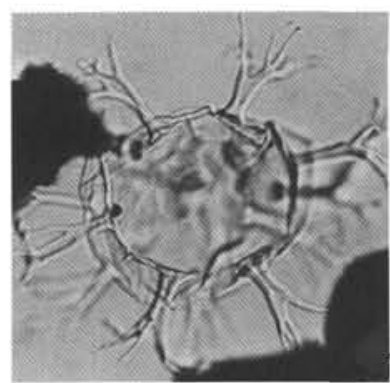

4

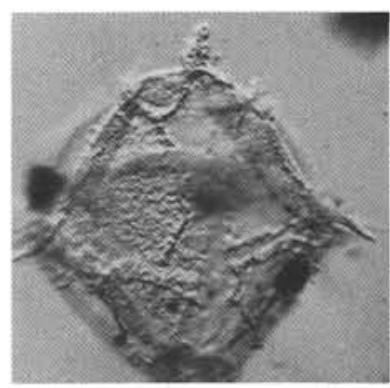

8

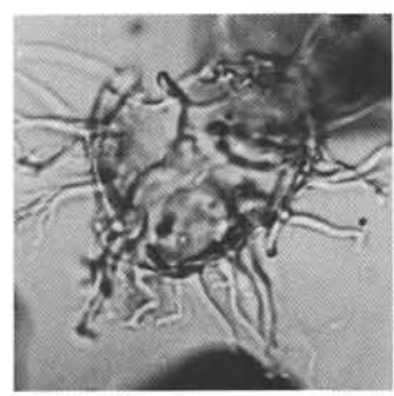

12

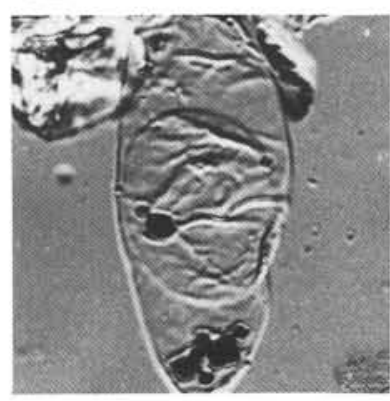

15

Plate 3. Photomicrographs of dinoflagellate cysts. Scale bar $=20 \mu \mathrm{m}$. 1. Meiourogonyaulax stoveri, Sample 103-638B-23R-2, 34-36 cm. Dorsal face, length $80 \mu \mathrm{m}$, slide 1: ST 30. 2. Muderongia perforata, Sample 103-638B-26R-5, 91-93 cm. Specimen folded, length $60 \mu \mathrm{m}$, slide 1: Y $39-$ 40. 3. Occisucysta duxburyi, Sample 103-638B-33R-2, $64-66 \mathrm{~cm}$. Apical view, diameter $80 \mu \mathrm{m}$, slide 1: MN 35 . 4. Oligosphaeridium dividuum, Sample 103-638B-30R-1, 144-146 cm. Length $84 \mu \mathrm{m}$, slide 1: 25 . 5. Oligosphaeridium verrucosum, Sample 103-638B-21R-2, 121-123 cm. Diameter $128 \mu \mathrm{m}$, slide 1: E 29-30. 6. Protoellipsodinium touile subsp. mugatae, Sample 103-638B-29R-3, 35-37 cm. Length $42 \mu \mathrm{m}$, slide 1: MN $32-33$. 7. Pseudoceratium pelliferum, Sample 103-638C-14R-1, 128-130 cm. Length $76 \mu \mathrm{m}$, slide 1: X 35 . 8. Rhynchodiniopsis aptiana, Sample 103-638B23R-2, 34-36 cm. Length, $136 \mu \mathrm{m}$, slide 1: 36. 9. Rhynchodiniopsis fimbriata, Sample 103-638C-3R-3, $41-43 \mathrm{~cm}$. Length $96 \mu \mathrm{m}$, slide 1: K 40. 10. Spiniferites multibrevis, Sample 103-638C-6R-2, 69-71 cm. Diameter $48 \mu \mathrm{m}$, slide 1: DE 30-31. 11. Subtilisphaera? terrula, Sample 103-638B21R-1, 121-123 cm. Length $48 \mu \mathrm{m}$, slide 2: Q 42-43. 12. Systematophora cf. areolata, Sample 103-638B-26R-2, 69-71 cm. Length $68 \mu \mathrm{m}$, slide 1: YZ 44-45. 13. Taleisphaera hydra, Sample 103-638B-23R-4, 40-42 cm. High focus view of dorsal face, diameter 77 $\mu \mathrm{m}$, slide 1: U 37-1. 14. Tehamadinium dodekovae, Sample 103-638C-3R-3, $41-43 \mathrm{~cm}$. Views of ventral face (A) and dorsal face at low focus (B); length $64 \mu \mathrm{m}$, slide 1: WX 35 . 15. Wallodinium krutzschii, Sample 103-638B-28R-6, $89-91 \mathrm{~cm}$. Length $86 \mu \mathrm{m}$, slide 1: Y 33-34. 